\title{
A 24-sectors direct power control-feedforward neural network method of DFIG integrated to dual-rotor wind turbine
}

\author{
Habib Benbouhenni \\ Department of Electrical \& Electronics Engineering, Faculty of Engineering and Architecture, Nisantasi University, \\ 34481742 Istanbul, Turkey
}

\begin{tabular}{l} 
Article Info \\
\hline Article history: \\
Received Jan 30, 2021 \\
Revised Apr 4, 2021 \\
Accepted May 27, 2021 \\
\hline Keywords: \\
24-sector DPC \\
Doubly-fed induction generator \\
Dual-rotor wind turbine \\
Feedforward neural network \\
Harmonic distortion
\end{tabular}

Harmonic distortion

\begin{abstract}
In this work, a 24-sector direct power control (24-sector DPC) of a doublyfed induction generator (DFIG) based dual-rotor wind turbine (DRWT) is studied. The major disadvantage of the 24-DPC control is the steady-state ripples in reactive and active powers. The use of 24 sectors of rotor flux, a feedforward neural network (FNN) algorithm is proposed to improve traditional 24-sector DPC performance and minimize significantly harmonic distortion (THD) of stator current and reactive/active power ripple. The proposed method is modeled and simulated by using MATLAB/Simulink software under different tests and compared with conventional 24-sector DPC.
\end{abstract}

This is an open access article under the CC BY-SA license.

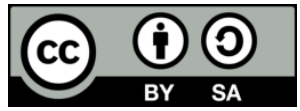

\section{Corresponding Author:}

Habib Benbouhenni

Department of Electrical \& Electronics Engineering

Faculty of Engineering and Architecture

Nisantasi University

Maslak Mahallesi, Taşyoncası Sokak, Bina Kodu: 34481742, İstanbul, Turkey

Email: habib.benbouenni@nisantasi.edu.tr

\section{INTRODUCTION}

The doubly-fed induction generator (DFIG) has many advantages compared to another generator because it is robust and facile to control. The DFIG rotor is connected via a back-to-back converter; the stator is directly linked to the grid. Various techniques for DFIG have been introduced in works of literature [1]-[9]. The direct vector control (DVC) based on intelligent space vector pulse width modulation (SVPWM) is proposed to control DFIG-based classical wind turbine (CWT) [10]. Fuzzy SVPWM reduces the active and reactive powers compared with neural SVPWM of DFIG controlled by neural second-order sliding mode (NSOSMC) [11], [12]. Neural sliding mode control (NSMC) is proposed to control the DFIG using neural SVPWM [13]. The NSMC method is proposed to minimize the harmonic distortion (THD) of stator current [14]. Fuzzy logic and PWM technique are combined to control the DFIG-based CWT [15]. Fuzzy SOSMC (FSOSMC) is proposed to reduce the active and reactive powers ripples of the DFIG using fuzzy SVPWM [16]. A Five-level fuzzy SVPWM technique was proposed to reduce the torque ripple of DFIG [17]. Fuzzy PWM reduces the THD value of stator current compared to neural SVPWM [18]. Intelligence indirect vector control (IVC) of DFIG using a two-level fuzzy SVPWM technique to reduces torque ripple [19]. The fourlevel neural SVPWM reduces ripples in the reactive power, torque, stator current, and active power compared to the three-level neural SVPWM technique [20]. The DVC control with five-level neural SVPWM reduced the torque ripple and stator current ripple compared to the DVC method using the two-level neural SVPWM technique [21]. The DVC method based on the fuzzy SVPWM technique reduced power ripples compared to 
the classical DVC strategy [22]. A hybrid SMC method was proposed to control DFIG, where the sign of SMC controller is replaced by neural algorithm [23]. The DTC method based on fuzzy super-twisting sliding mode (FSTSM) algorithm (DTC-FSTSM) reduced the reactive and active powers compared to the DTCNSTSM control scheme [24]. The SVPWM technique reduces the harmonic distortion of stator current and torque ripple compared to the traditional PWM strategy of DFIG controlled by the fuzzy SMC method [25].

A DTC method was proposed based on the neural STSM algorithm to minimize the torque and rotor flux ripples of DFIG-based CWT [26]. The five-level fuzzy SVPWM technique minimizes the active and reactive powers ripples compared to the five-level neural SVPWM technique of the DFIG controlled by the neural SOSMC method [27]. A DVC method was proposed to control DFIG using the seven-level SVPWM technique [28]. The DVC method is based on the four-level fuzzy SVPWM technique to regulate the reactive and active powers of the DFIG [29]. The IVC method was proposed to control DFIG using the five-level fuzzy SVPWM technique [30]. DTC method and fuzzy STSM algorithm are combined to minimize the torque and stator current ripples of the DFIG-based CWT [31]. The fuzzy SVPWM technique reduces the THD value of stator current compared to the classical SVPWM technique of DFIG controlled by the fuzzy SOSM method [32]. The neural SOSM method reduces the reactive and active powers ripples compared to the neural SMC control of DFIG [33]. The fuzzy PWM strategy minimizes the torque ripple and the THD value of stator current compared to the classical SVPWM technique of DFIG controlled by the neural SMC control scheme [34]. The DVC control scheme based on the three-level neural SVPWM technique was proposed to control DFIG [35]. DTC control scheme based on artificial neural networks (ANNs) to reduces active and reactive powers ripples of DFIG using the seven-level torque hysteresis comparator [36].

SVPWM technique and adaptive-network-based fuzzy inference system (ANFIS) algorithm are combined to control DFIG using the NSOSMC method [37]. ANFIS-SOSMC method was proposed to regulate the active and reactive powers of DFIG using the seven-level neural SVPWM technique [38]. SMC and ANFIS algorithms are combined to control DFIG [39]. Neural SVPWM reduced the ripples in the torque, active and reactive powers compared to neural PWM of DFIG controlled by the fuzzy SMC method [40]. The DVC control using the seven-level SVPWM and two-level SVPWM technique, where the torque ripple is reduced when using the seven-level SVPWM technique [41]. DVC control was proposed to control the DFIG using seven-level fuzzy SVPWM [42]. The DTC method was proposed to reduce the power ripple of the DFIG using neural proportional-integral (NPI) [43]. DTC technique and ANFIS-STSM algorithm are combined to reduce the torque ripple of DFIG-based CWT [44].

Direct power control (DPC) is a technique for solving both problems that are based on direct torque control (DTC). The DPC control is a simple method compared to field-oriented control (FOC) and easy to implement. The DPC control scheme uses two hysteresis comparators and one switching table, where one hysteresis comparator for reactive power and the other for active power. The DPC control can reduce the ripples of torque, active power, stator flux, and reactive power of the DFIG-based CWT. On the other hand, this strategy was proposed by Nogouchi in 1998 [45]. The classical DPC method uses a two-phase inverter to output a basic voltage vector in one control period to realize the direct control of reactive and active powers on the third harmonic and fundamental plans simultaneously. The DPC is a technique scheme with simplicity, fast response, and independence of DFIG parameters. Various research papers are published on the DPC method of DFIG [46]-[55]. In this paper, we propose to use 24-sectors DPC with neural algorithms to reduces the active and reactive powers of the DFIG-based dual rotor wind turbine (DRWT) systems and compared the obtained simulation results with classical 24-sectors DPC strategy.

\section{DUAL-ROTOR WIND TURBINE}

Figure 1 represents a block diagram of the DRWT with DFIG. The goal of the DRWT is to increase the torque. DRWT control is very difficult compared to classical wind turbines. DRWT consists of two wind turbines. The first turbine is the main turbine and the second turbine is the auxiliary. The DRWT gives more aerodynamic torque value compared to the classical wind turbine. The torque value of DRWT is the combination of the torque of main and auxiliary turbines.

The main turbine torque equation is given by (1) [56].

$T_{M}=\frac{1}{2 \lambda_{M}^{3}} \cdot A \cdot \rho \cdot \pi \cdot R_{A}^{5} \cdot C_{P} \cdot w_{M}^{2}$

The auxiliary turbine gives us torque.

$$
T_{A}=\frac{1}{2 \lambda_{A}^{3}} \cdot A \cdot \rho \cdot \pi \cdot R_{A}^{5} \cdot C_{P} \cdot w_{A}^{2}
$$


With $\lambda_{\mathrm{A}}, \lambda_{\mathrm{M}}$ : the tip speed ration of the auxiliary and main turbines, $\mathrm{R}_{\mathrm{M}}, \mathrm{R}_{\mathrm{A}}$ : Blade radius of the main and auxiliary turbines, $\rho$ : the air density and $\mathrm{w}_{\mathrm{A}}, \mathrm{w}_{\mathrm{M}}$ the mechanical speed of the auxiliary and main turbines.

Speed ratios equation of the auxiliary turbines is given (3).

$\lambda_{A}=\frac{w_{A} \cdot R_{A}}{V_{1}}$

Speed ratios equation of the main turbines is given (4).

$\lambda_{M}=\frac{w_{M} \cdot R_{M}}{V_{M}}$

Where, $V_{M}$ is the speed of the unified wind on main turbine and $V_{1}$ is the wind speed on an auxiliary turbine.

The total aerodynamic torque as shown by (5).

$T_{D R W T}=T_{T}=T_{M}+T_{A}$

Where, $\mathrm{T}_{\mathrm{M}}$ is the MT torque, $\mathrm{T}_{\mathrm{A}}$ is the AT torque, $\mathrm{T}_{\mathrm{T}}$ is the total torque.

The wind speed on the main turbine is given (6) [57].

$$
V_{x}=V_{1}\left(1-\frac{1-\sqrt{\left(1-C_{T}\right)}}{2}\left(1+\frac{2 \cdot x}{\sqrt{1+4 \cdot x^{2}}}\right)\right)
$$

With Vx: is the velocity of the disturbed wind between rotors at point $\mathrm{x}$ and $\mathrm{C}_{\mathrm{T}}$ the trust coefficient, which is taken to be 0.9; $\mathrm{x}$ : the non-dimensional distance from the auxiliary rotor disk. So, with respect to $\mathrm{x}=15$, the value of the Vx close to the main rotor is computable (rotors are located 15 meters apart from each other) [58]. The $\mathrm{Cp}$ is given (7).

$$
C_{p}(\lambda . \beta)=\frac{1}{\lambda+0.08 \beta}-\frac{0.035}{\beta^{3}+1}
$$

With $\beta$ is pitch angle.

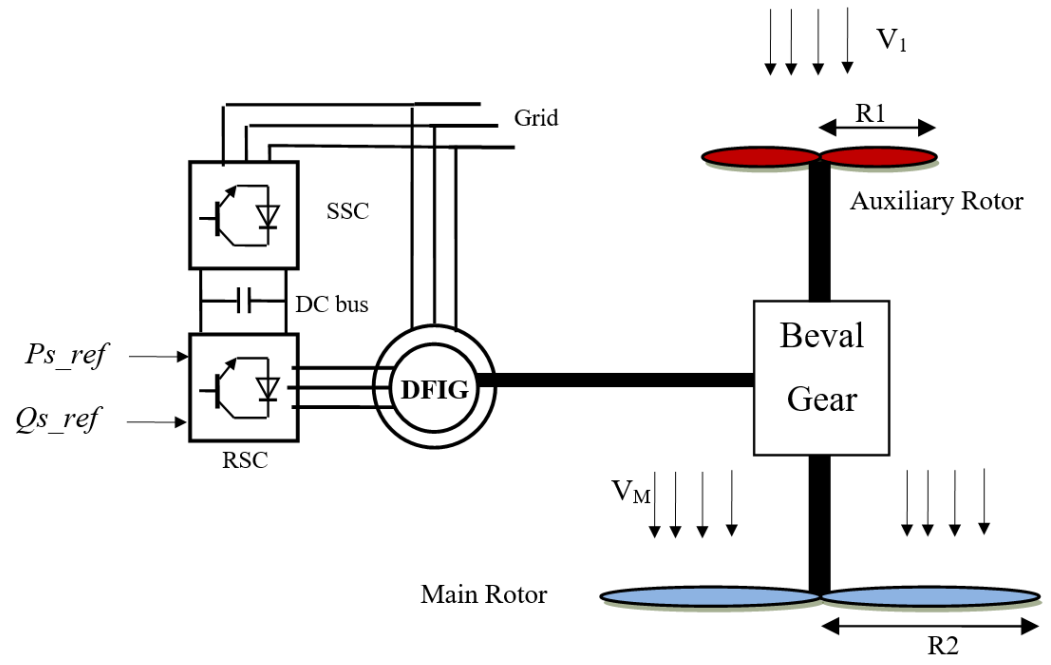

Figure 1. Block diagram of the DRWT

Figures 2-7 show that the auxiliary wind speed, main wind speed, auxiliary mechanical power, main mechanical power, rotational speed, and total mechanical power $(\mathrm{Pt})$ of DRWP systems respectively. It can be seen that the mechanical power is related to main and auxiliary wind speed. 


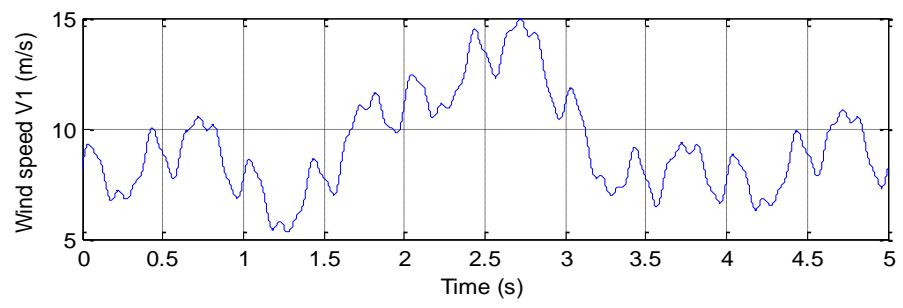

Figure 2. Wind speed of auxillary turbine

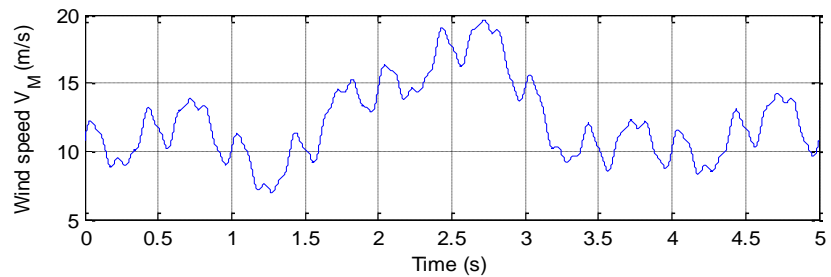

Figure 3. Wind speed of main turbine

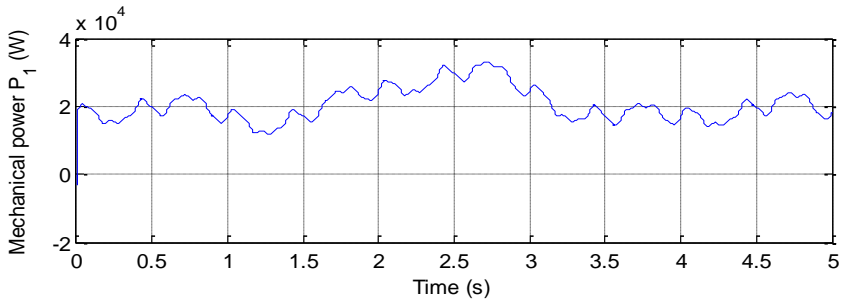

Figure 4. Mechanical power of auxillary turbine

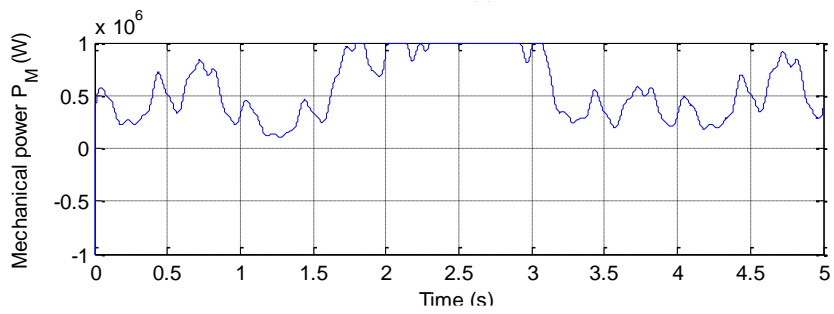

Figure 5. Mechanical power of main turbine

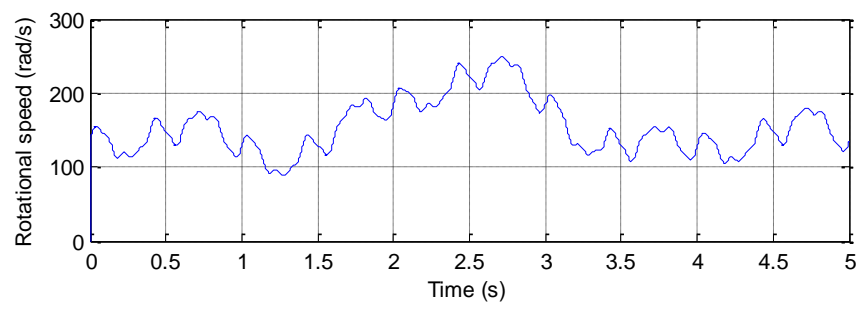

Figure 6. Rotational speed 


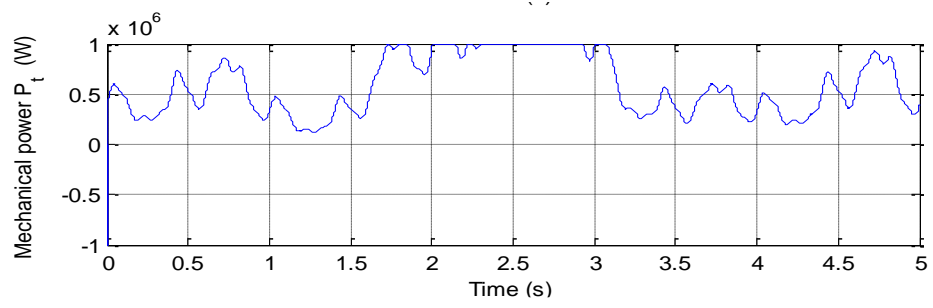

Figure 7. Total mechanical power of DRWP system

\section{24 SECTORS DPC METHOD}

DPC is a method with fast response, simplicity, and independence of DFIG parameters [48], [51]. It was first introduced by Nogouchi. In this part, we propose to use 24 sectors of rotor flux. The designed DPC strategy achieves sinusoidal stator current waveform compared to the classical DPC method and FOC command. The 24-DPC command goal is to regulate the active and reactive powers of the DFIG-based DRWT. The 24-DPC, which is designed to minimize active and reactive power oscillations of the DFIGDRWT, is shown in Figure 8. Figure 9 shows the three-level inverter vectors representations.

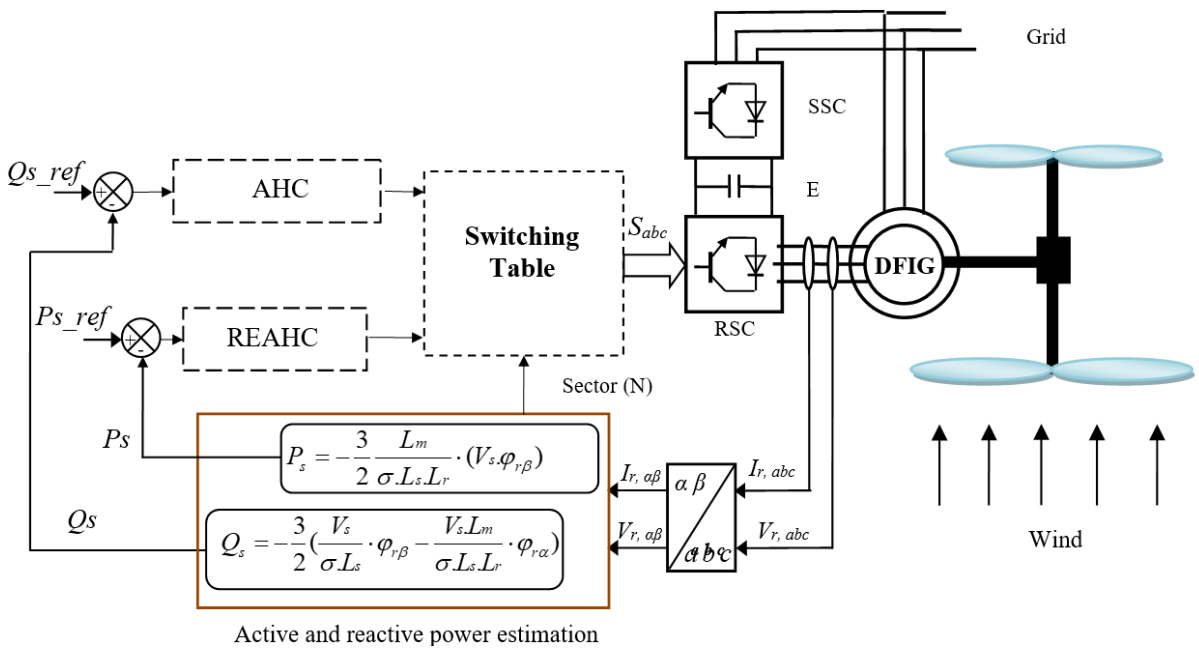

Figure 8. 24-DPC system of three-phase DFIG

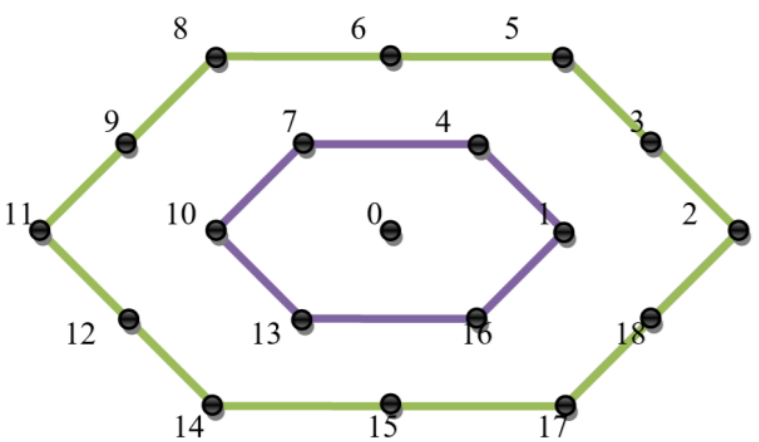

Figure 9. Three-level inverter vectors representations.

The DPC performances can be ensured by using a switching table that can be seen in Table 1, to select the switching voltage vector. The inverter connected to the DFIG must provide the necessary complementary frequency to maintain a constant stator frequency. 
Table 1. Switching table of 24-DPC method

\begin{tabular}{|c|c|c|c|c|c|c|c|c|c|c|}
\hline \multirow{4}{*}{$\mathrm{N}$} & \multicolumn{10}{|c|}{$\mathrm{Hq}$} \\
\hline & \multirow{2}{*}{\multicolumn{2}{|c|}{2}} & \multirow{2}{*}{\multicolumn{2}{|c|}{1}} & \multirow{2}{*}{\multicolumn{2}{|c|}{$\begin{array}{c}0 \\
\mathrm{Hp}\end{array}$}} & \multirow{2}{*}{\multicolumn{2}{|c|}{-1}} & \multirow{2}{*}{\multicolumn{2}{|c|}{-2}} \\
\hline & & & & & & & & & & \\
\hline & 1 & 0 & 1 & 0 & 1 & 0 & 1 & 0 & 1 & 0 \\
\hline 1 & 17 & 22 & 3 & 2 & 0 & 0 & 5 & 13 & 25 & 20 \\
\hline 2 & 17 & 22 & 3 & 2 & 0 & 0 & 5 & 13 & 25 & 20 \\
\hline 3 & 23 & 17 & 4 & 3 & 7 & 7 & 6 & 8 & 20 & 26 \\
\hline 4 & 23 & 17 & 4 & 3 & 7 & 7 & 6 & 8 & 20 & 26 \\
\hline 5 & 18 & 23 & 11 & 10 & 14 & 14 & 13 & 1 & 26 & 15 \\
\hline 6 & 18 & 23 & 11 & 10 & 14 & 14 & 13 & 1 & 26 & 15 \\
\hline 7 & 24 & 18 & 12 & 11 & 0 & 0 & 8 & 2 & 15 & 21 \\
\hline 8 & 24 & 18 & 12 & 11 & 0 & 0 & 8 & 2 & 15 & 21 \\
\hline 9 & 19 & 24 & 5 & 4 & 7 & 7 & 1 & 9 & 21 & 16 \\
\hline 10 & 19 & 24 & 5 & 4 & 7 & 7 & 1 & 9 & 21 & 16 \\
\hline 11 & 4 & 0 & 2 & 5 & 7 & 1 & 2 & 10 & 16 & 22 \\
\hline 12 & 4 & 0 & 2 & 5 & 7 & 1 & 2 & 10 & 16 & 22 \\
\hline 13 & 20 & 25 & 13 & 12 & 0 & 0 & 9 & 3 & 22 & 17 \\
\hline 14 & 20 & 25 & 13 & 12 & 0 & 0 & 9 & 3 & 22 & 17 \\
\hline 15 & 26 & 20 & 8 & 13 & 7 & 7 & 10 & 4 & 17 & 23 \\
\hline 16 & 26 & 20 & 8 & 13 & 7 & 7 & 10 & 4 & 17 & 23 \\
\hline 17 & 15 & 26 & 1 & 6 & 14 & 14 & 3 & 11 & 23 & 18 \\
\hline 18 & 15 & 26 & 1 & 6 & 14 & 14 & 3 & 11 & 23 & 18 \\
\hline 19 & 21 & 15 & 2 & 1 & 0 & 0 & 4 & 12 & 18 & 24 \\
\hline 20 & 21 & 15 & 2 & 1 & 0 & 0 & 4 & 12 & 18 & 24 \\
\hline 21 & 16 & 21 & 9 & 8 & 7 & 7 & 11 & 5 & 24 & 19 \\
\hline 22 & 16 & 21 & 9 & 8 & 7 & 7 & 11 & 5 & 24 & 19 \\
\hline 23 & 22 & 16 & 10 & 9 & 14 & 14 & 12 & 6 & 19 & 25 \\
\hline 24 & 22 & 16 & 10 & 9 & 14 & 14 & 12 & 6 & 19 & 25 \\
\hline
\end{tabular}

The magnitude of stator flux, which can be estimated by (8) [26].

$\left\{\begin{array}{l}\Psi_{s \alpha}=\int_{0}^{t}\left(V_{s \alpha}-R_{s} i_{s \alpha}\right)^{d t} \\ \Psi_{s \beta}=\int_{0}^{t}\left(V_{s \beta}-R_{s} i_{s \beta}\right)^{d t}\end{array}\right.$

The stator flux amplitude is given by (9).

$\Psi_{s}=\sqrt{\Psi_{s \alpha}^{2}+\Psi_{s \beta}^{2}}$

Where (10).

$\left|\overline{\Psi_{S}}\right|=\frac{\left|\overline{V_{S}}\right|}{w_{S}}$

The stator flux angle is calculated by (11).

$\theta_{S}=\operatorname{arctg}\left(\frac{\Psi_{S \beta}}{\Psi_{S \alpha}}\right)$

Reactive and active powers is estimated using (12) and (13) [53].

$$
\begin{aligned}
& P_{s}=-\frac{3}{2} \frac{L_{m}}{\sigma \cdot L_{s} \cdot L_{r}} \cdot\left(V_{s} \cdot \varphi_{r \beta}\right) \\
& Q_{s}=-\frac{3}{2}\left(\frac{V s}{\sigma . L s} \cdot \phi_{r \beta}-\frac{V s . L m}{\sigma . L s . L r} \cdot \phi_{r \alpha}\right.
\end{aligned}
$$

Where (14), (15) and (16).

$$
\sigma=1-\frac{M^{2}}{L_{r} L_{S}}
$$




$$
\begin{aligned}
& \Psi_{s \alpha}=\sigma L_{r} L_{r \alpha}+\frac{M}{L_{s}} \Psi_{s} \\
& \Psi_{s \beta}=\sigma L_{r} L_{r \beta}
\end{aligned}
$$

The active and reactive powers can be reformulated by inducing angle $\lambda$ between the rotor and stator vectors as (17) and (18) [52].

$$
\begin{aligned}
& P_{S}=-\frac{3}{2} \frac{L_{m}}{\sigma \cdot L_{s} \cdot L_{r}} w_{s}\left|\psi_{\mathrm{s}}\right|\left|\psi_{\mathrm{r}}\right| \sin (\lambda) \\
& Q_{S}=-\frac{3}{2} \frac{w_{s}}{\sigma \cdot L_{s}}\left|\psi_{\mathrm{s}}\right|\left(\frac{M}{L_{r}}\left|\psi_{\mathrm{r}}\right| \cos (\lambda)\left|\psi_{\mathrm{r}}\right|\right)
\end{aligned}
$$

The derivation of the reactive and active powers can given by (19) and (20).

$$
\begin{aligned}
& \frac{d P_{S}}{d_{t}}=-\frac{3}{2} \frac{L_{m}}{\sigma \cdot L_{s} \cdot L_{r}} w_{S}\left|\Psi_{\mathrm{s}}\right| \frac{d\left(\left|\Psi_{\mathrm{r}}\right| \sin (\lambda)\right)}{d_{t}} \\
& \frac{d Q_{s}}{d_{t}}=-\frac{3}{2} \frac{M \cdot w_{S}}{\sigma \cdot r \cdot L_{S}}\left|\Psi_{\mathrm{s}}\right|\left(\frac{d\left(\left|\Psi_{\mathrm{r}}\right| \cos (\lambda)\right)}{d_{t}}\right)
\end{aligned}
$$

A two-level hysteresis comparator is used for active error as shown in Figure 10. For stator reactive power error, the hysteresis comparator used is five-level as shown in Figure 11.

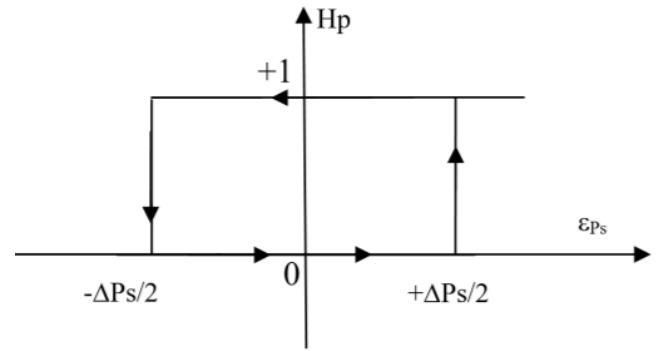

Figure 10. Active power hysteresis comparator

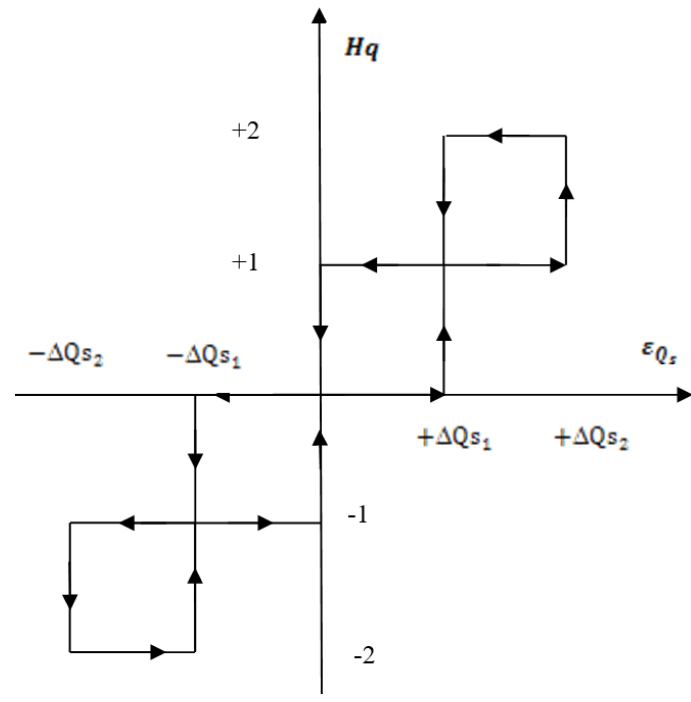

Figure 11. Reactive power hysteresis comparator

\section{DPC-FNN METHOD}

The 24-sectors DPC strategy with the FNN algorithm is a robust, simple, and easy command to control the reactive and active power of the DFIG-based DRWP systems. Figure 12 shows the structure of the system implemented with this proposed command. As shown in this figure, we can see that the inverter of the DFIG is directly controlled by the FNN algorithm. In this proposed command, the lookup table of the classical DPC command is replaced by the FNN algorithm. On the other hand, the input of active and reactive powers hysteresis comparators is the errors between the reference and measured active and reactive powers. An FNN algorithm is used to command the inverter of the DFIG and reduce the active and reactive powers. 


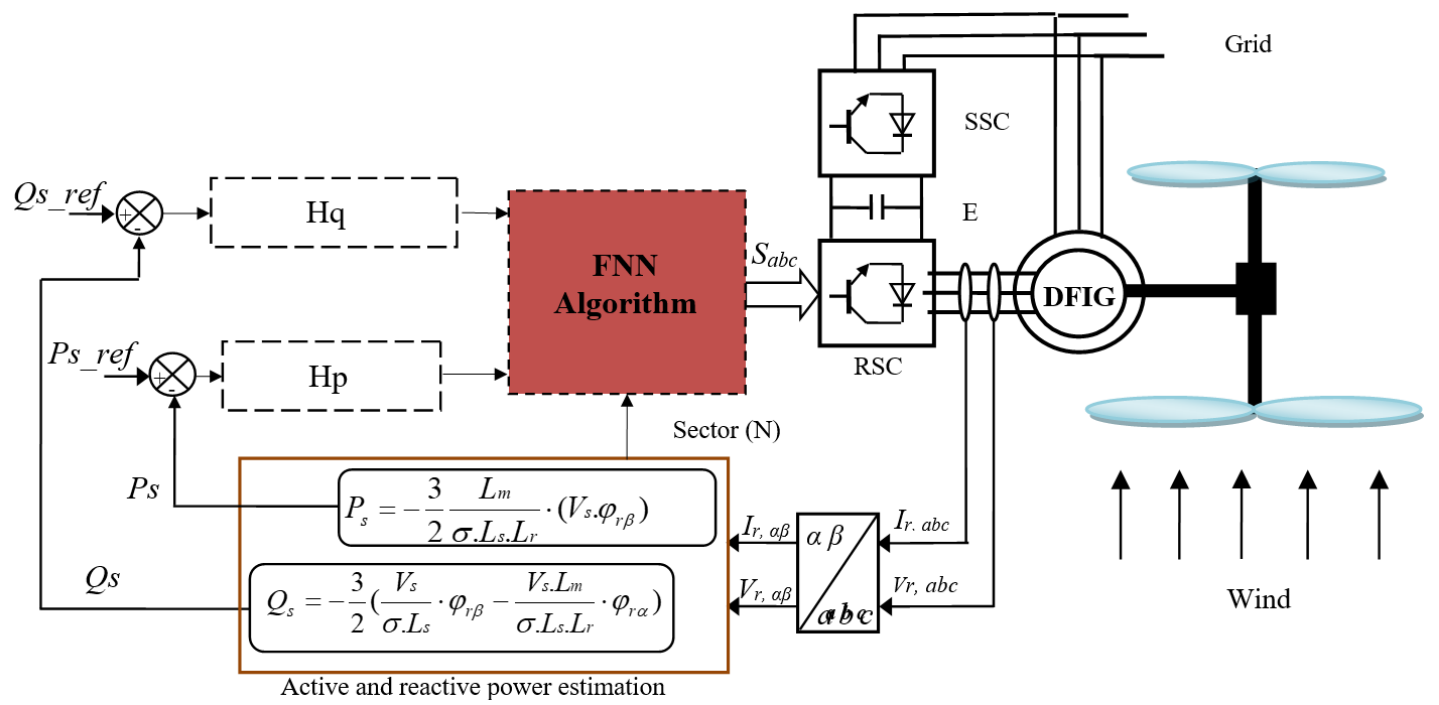

Figure 12. 24-sectors DPC strategy of three-phase DFIG with the application of FNN algorithm

The structure of the FNN controller is illustrated in Figure 13. The block diagram of layer 1 and layer 2 is shown in Figure 14 and Figure 15 respectively.

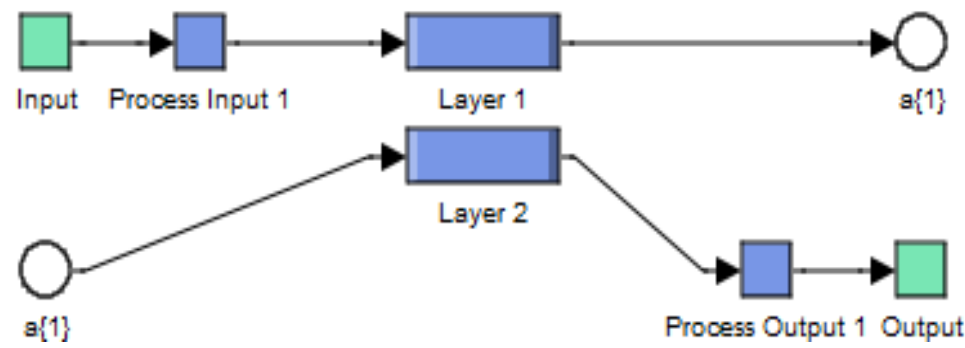

Figure 13. Block diagram of the FNN controller

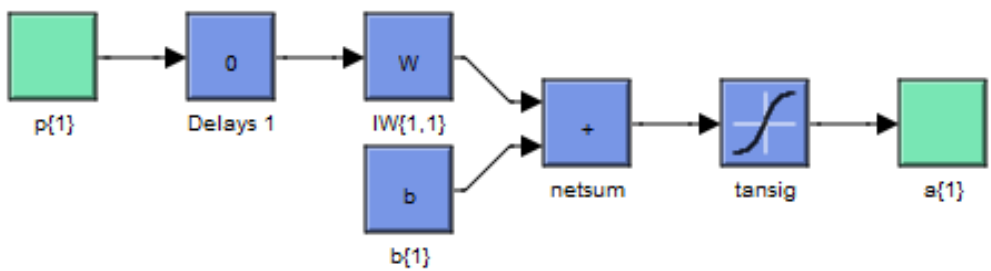

Figure 14. Layer 1

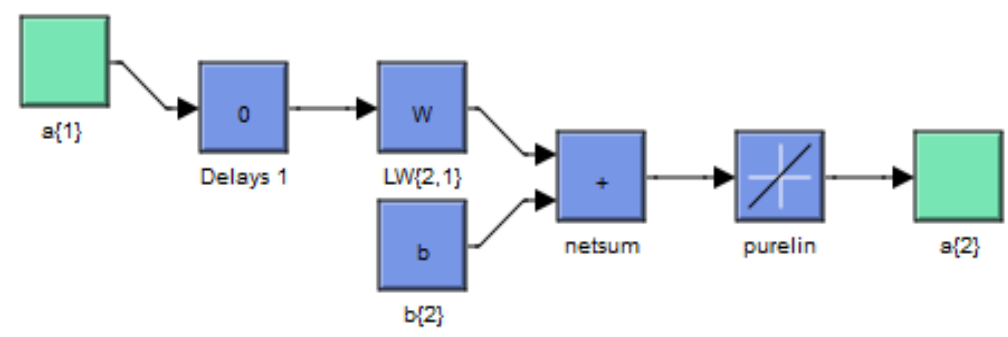

Figure 15. Layer 2 


\section{RESULTS AND DISCUSSION}

The simulation results of 24-sectors DPC with the FNN algorithm of the DFIG are compared with the classical 24-sectors DPC strategy. The DFIG used in our study has the following parameters: nominal active power of the stator: $P_{s n}=1.5 \mathrm{MW}$, stator voltage: $380 / 696 \mathrm{~V}$, two poles, stator voltage frequency: $50 \mathrm{~Hz}$; $R_{s}=0.012 \Omega, R_{r}=0.021 \Omega, L_{s}=0.0137 \mathrm{H}, L_{r}=0.0136 \mathrm{H}, L_{m}=0.0135 \mathrm{H}, J=1000 \mathrm{~kg} \cdot \mathrm{m}^{2}$ and $f_{r}=0.0024 \mathrm{Nm} / \mathrm{s}$ [46], [47].

Figure 16 and Figure 17 show the stator current THD of the DFIG-based DRWP systems obtained using Fast Fourier Transform strategy for 24-sectors DPC control scheme with FNN algorithm (24-sectors DPC-FNN) and classical 24-sectors DPC respectively. It can be observed that the THD is minimized for the 24-sectors DPC-FNN strategy $(\mathrm{THD}=0.40 \%)$ when compared to the classical 24-sectors DPC $(\mathrm{THD}=0.80 \%)$. Table 2 shows the comparative analysis of THD values.

The simulation waveforms of the reference and measured active power of the DFIG-based DRWP system are shown in Figure 18 to compare the performance of the 24-sectors DPC system with the application of the FNN algorithms with the performance of the classical 24-sectors DPC strategy. The active power tracks almost perfectly their reference value $\left(P_{s-r e f}\right)$. On the other hand, the amplitudes of the oscillations of the active power are smaller and occur in a short period of time in comparison with the oscillations obtained for the 24-sectors DPC strategy that can be seen in Figure 21.

For the 24-sectors DPC-FNN and classical 24-sectors DPC strategy, the reactive power track almost perfectly their reference value as shown in Figure 19. Moreover, the 24-sectors DPC-FNN strategy reduced the reactive power ripple compared to the classical 24-sectors DPC strategy as shown in Figure 22.

The trajectory of the measured magnitude of the stator current is shown in Figure 20. It can be stated that the amplitudes of the stator currents depend on the state of the drive system and the value of the load reactive/active power of the DFIG-based DRWP systems. Also, the 24-sectors DPC-FNN strategy minimized the stator current ripple compared to the classical 24-sectors DPC strategy as shown in Figure 23.

Table 2. Comparative analysis of THD value

\begin{tabular}{ccc}
\hline & \multicolumn{2}{c}{ THD (\%) } \\
& 24-sectors DPC & 24-sectors DPC-FNN \\
\hline Stator current & 0.80 & 0.40 \\
\hline
\end{tabular}
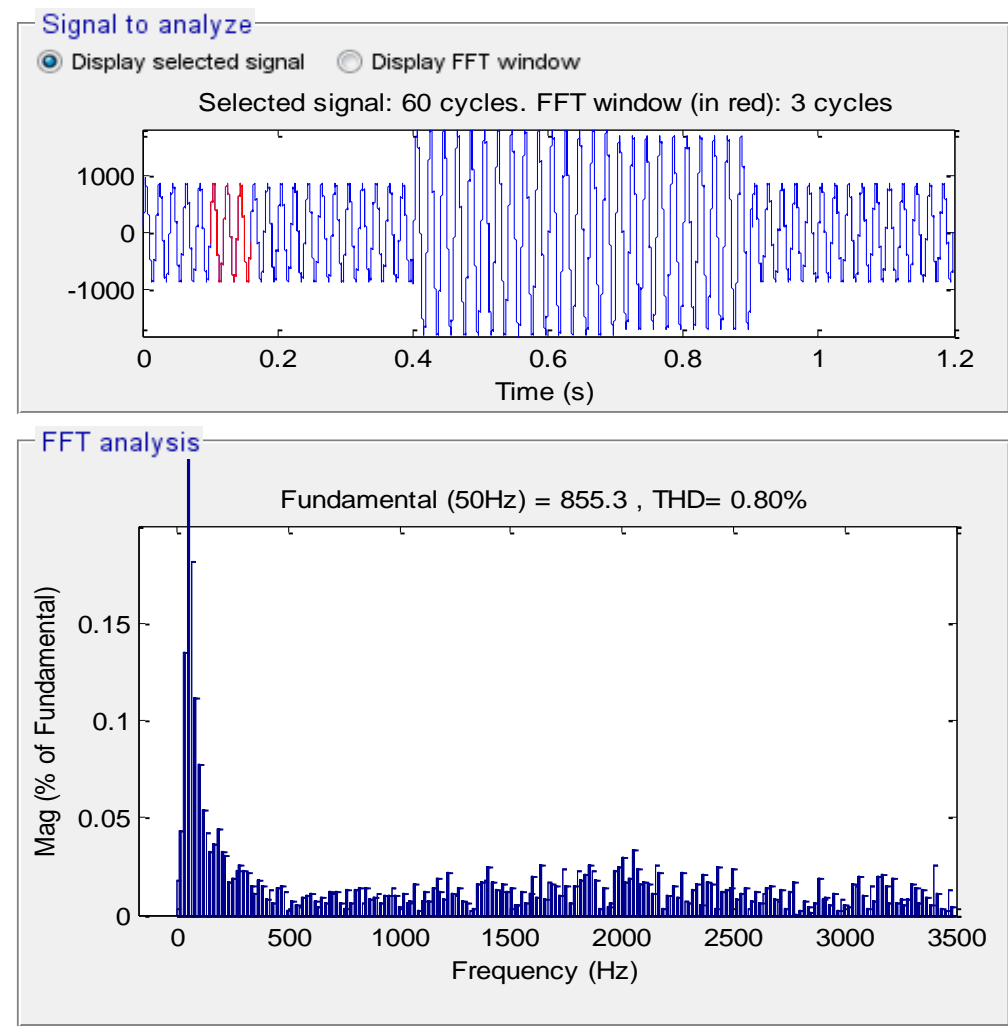

Figure 16. Spectrum harmonic of stator current (24-sectors DPC) 

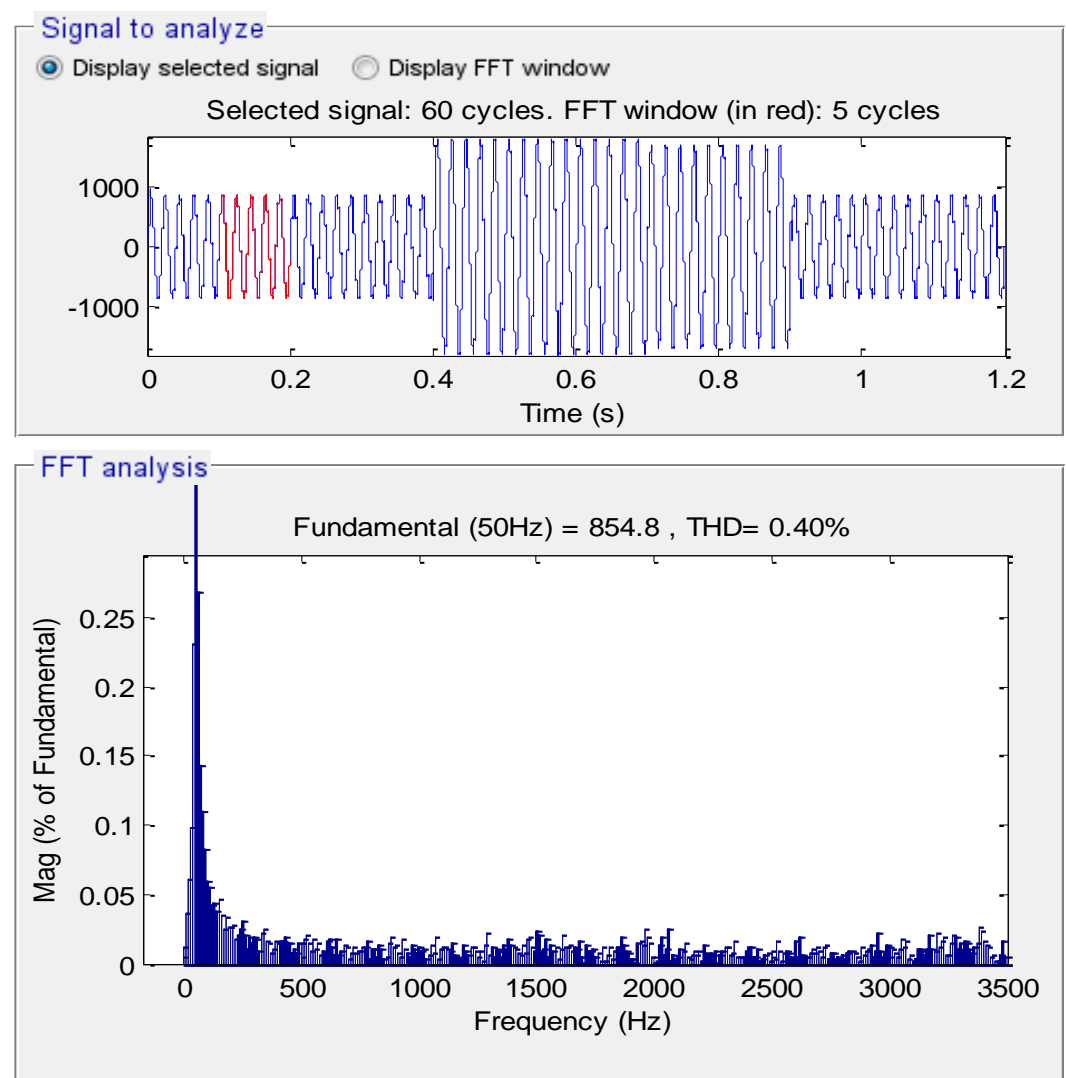

Figure 17. Spectrum harmonic of stator current (24-sectors DPC-FNN)

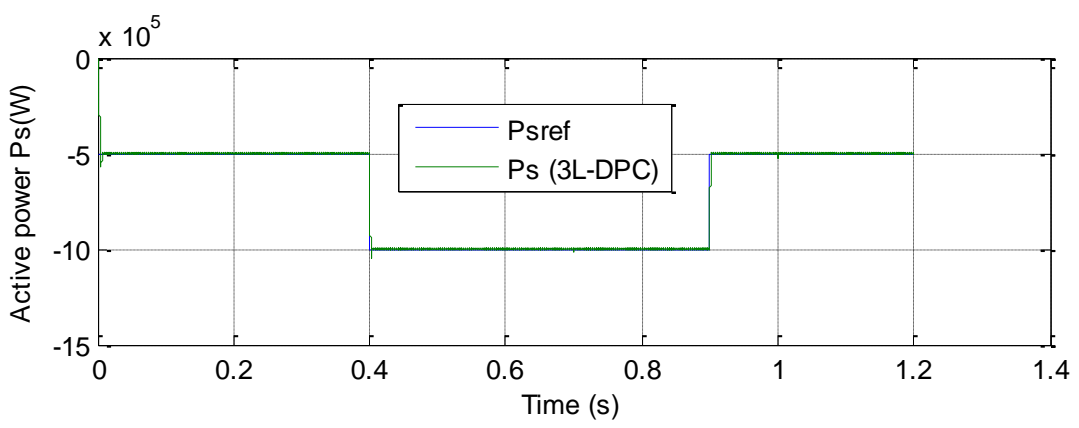

(a)

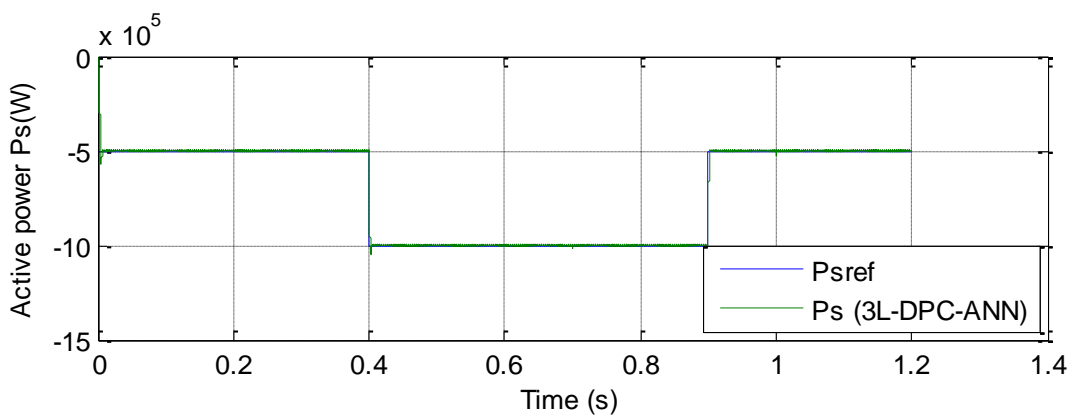

(b)

Figure 18. Active power: (a) 24-sectors DPC, (b) 24-sectors DPC-FNN 


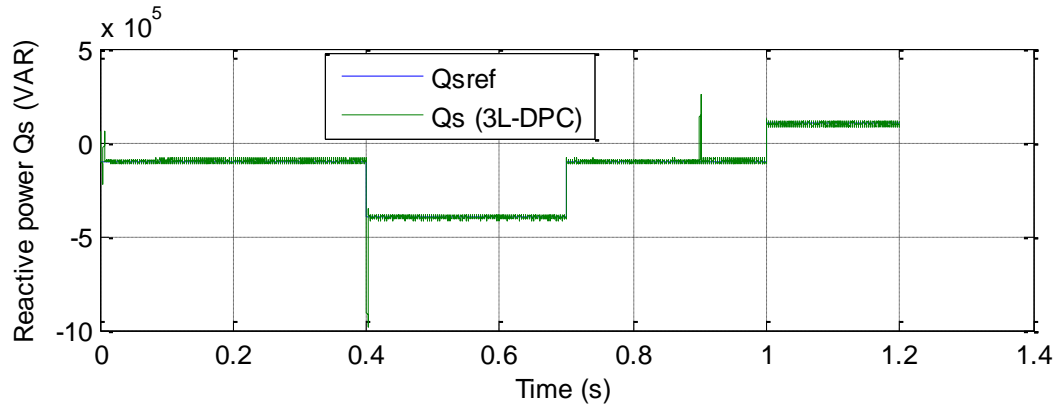

(a)

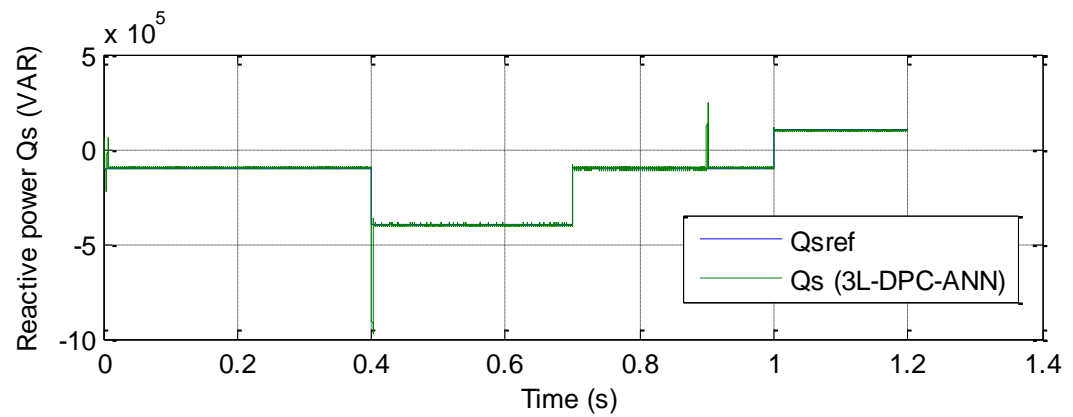

(b)

Figure 19. Reactive power: (a) 24-sectors DPC, (b) 24-sectors DPC-FNN

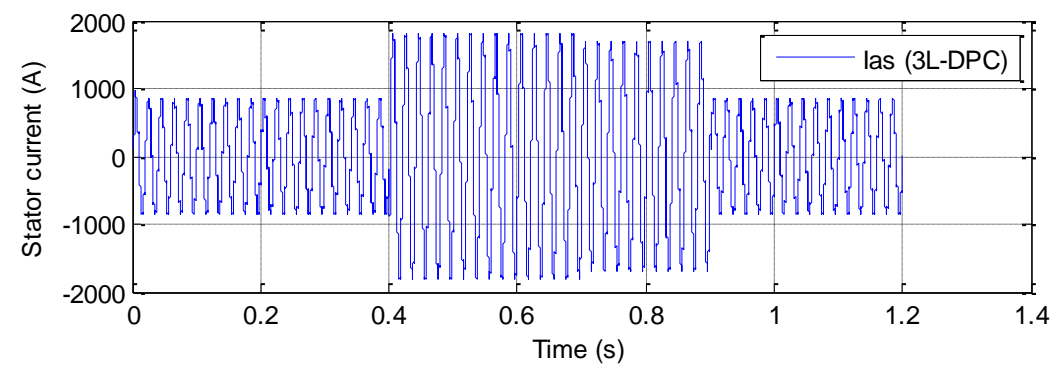

(a)

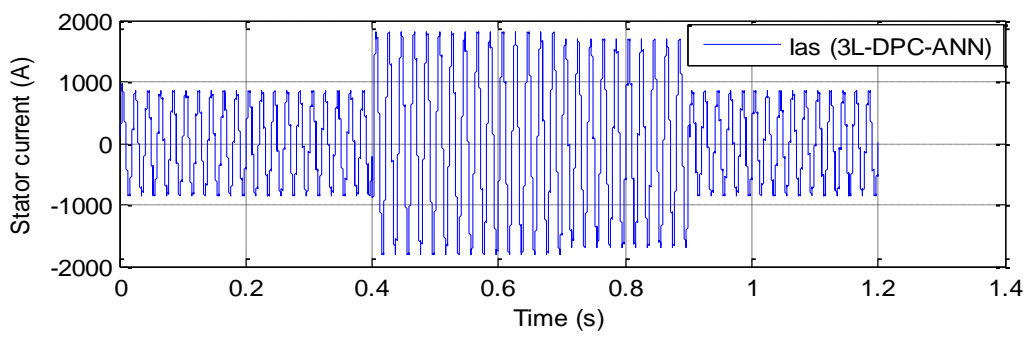

(b)

Figure 20. Stator current: (a) 24-sectors DPC, (b) 24-sectors DPC-FNN 


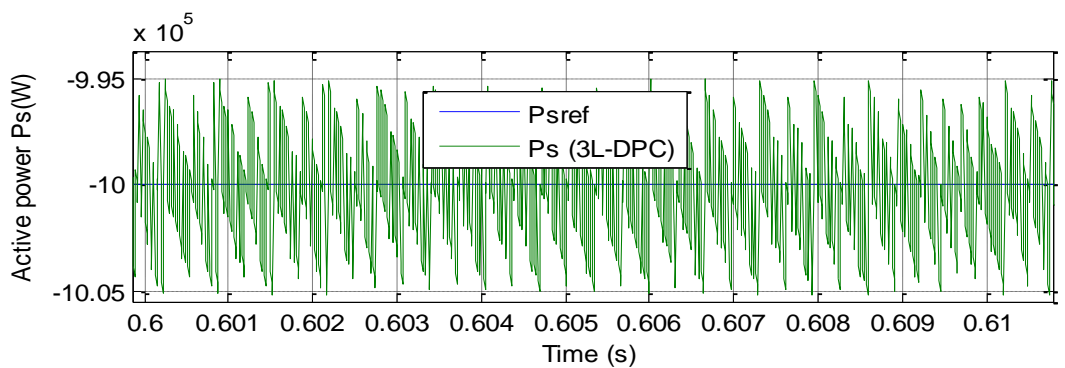

(a)

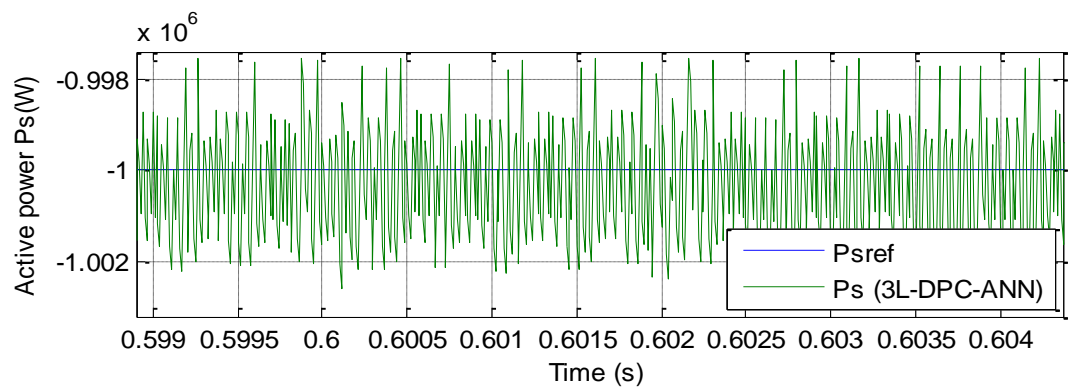

(b)

Figure 21. Zoom in the active power: (a) 24-DPC, (b) 24-sectors DPC-FNN

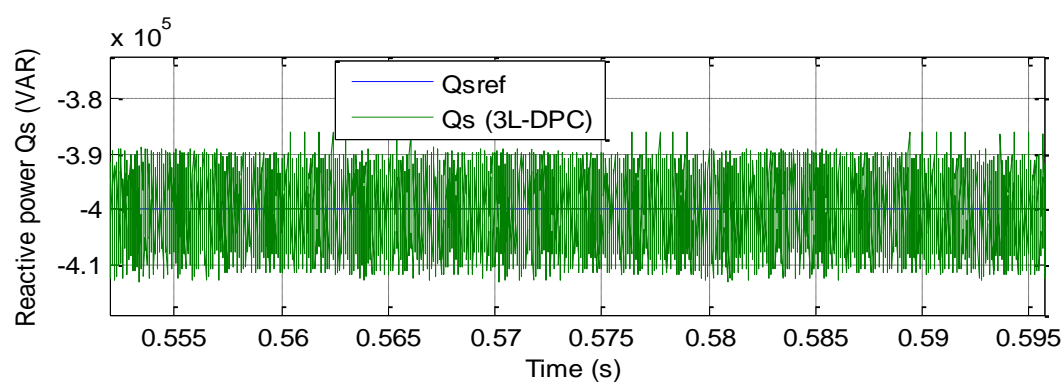

(a)

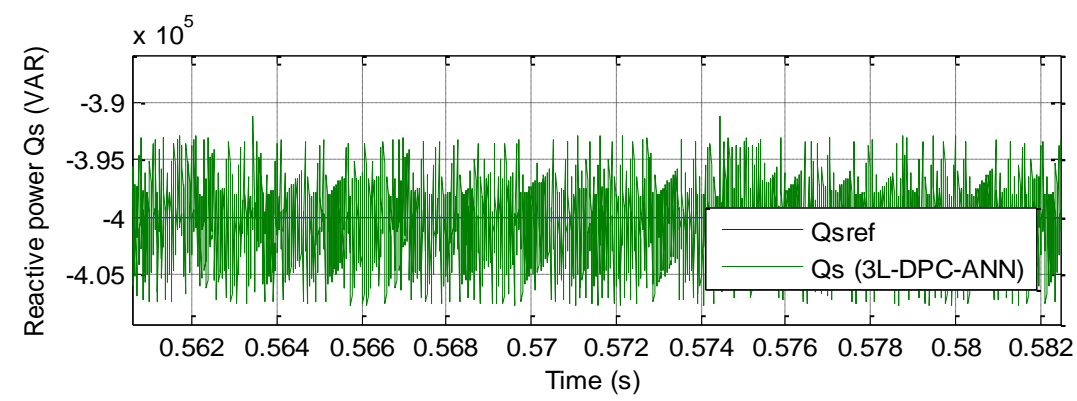

(b)

Figure 22. Zoom in the reactive power: (a) 24-sectors DPC, (b) 24-sectors DPC-FNN 


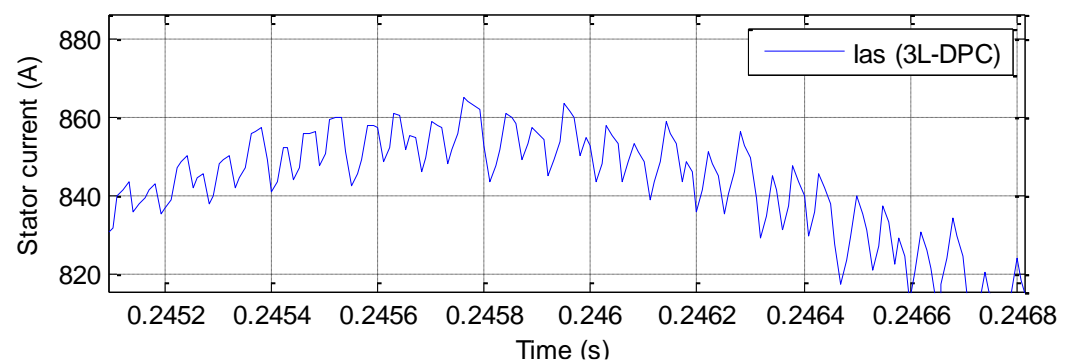

(a)

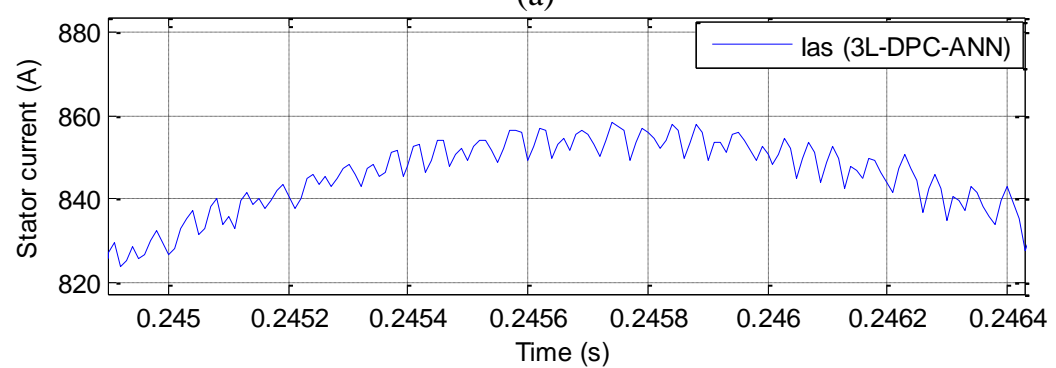

(b)

Figure 23. Zoom in the stator current: (a) 24-sectors DPC, (b) 24-sectors DPC-FNN

On the other hand, this designed strategy reduced the THD value of current compared to other techniques as shown in Table 3.

Table 3. Compare results with other methods

\begin{tabular}{llc}
\multicolumn{3}{c}{ Table 3. Compare results with other methods } \\
\hline & & THD (\%) \\
\hline Ref. [59] & DPC & 4.88 \\
Ref. [60] & VFDPC & 4.19 \\
Ref. [60] & FOC & 3.7 \\
Ref. [61] & SMC & 3.7 \\
Ref. [62] & SOCSM-DTC & 3.05 \\
Ref. [63] & & 0.98 \\
Ref. [64] & & 0.43 \\
Designed strategies & 24 sectors DPC & 0.50 \\
& 24 sectors DPC-FNN & 0.80 \\
\hline
\end{tabular}

\section{CONCLUSION}

The main objective of this work was to develop a robust DPC strategy of a DFIG integrated into a DRWP system. The basic idea was to use a neural algorithm associated with a 24-sector DPC strategy. Numerical simulations by Matlab software have been developed to test the effectiveness provided by the strategies used. The results of the simulation obtained show well the superiority of the designed strategy (24sectors DPC-FNN) compared to the conventional one (24-sectors DPC) especially in the attenuation of the fluctuations of the powers supplied and the performances against parametric variations.

\section{REFERENCES}

[1] H. Benbouhenni, "Neuro-sconde order sliding mode field oriented control for DFIG based wind turbine," International Journal of Smart Grid, vol. 2, no. 4, pp. 209-217, 2018.

[2] S. Massoum, A. Meroufel, A. Massoum and P. Wira, "A direct power control of the doubly-fed induction generator based on the SVM strategy," Elektrotehniski Vestnik, vol. 84, no. 5, pp. 235-240, 2017. [Onlline]. Available: https://ev.fe.uni-lj.si/5-2017/Massoum.pdf.

[3] R. Ettouil, K. Chabir and M. N. Abdelkrim, "Optimal synergetic control for wind turbine system," The International Journal of Engineering and Science, vol. 7, no. 5, pp. 44-48, 2018. [Online]. Available: https://www.theijes.com/papers/vol7-issue5/Version-1/G0705014448.pdf.

[4] J. Qian, K. Li, H. Wu, J. Yang and X. Li, "Synergetic control of grid-connected photovoltaic systems," International Journal of Photoenergy, vol. 2017, p. 5051489, 2017, doi: 10.1155/2017/5051489. 
[5] H. Benbouhenni, Z. Boudjema and A. Belaidi, "DFIG-based wind turbine system using three-level neural space vector modulation technique," Majlesi Journal of Mechatronic Systems, vol. 7, no. 2, pp. 35-45, 2018. [Online]. Available: http://journals.iaumajlesi.ac.ir/ms/index/index.php/ms/article/view/358.

[6] H. Benbouhenni, "Comparative study between different vector control methods applied to DFIG wind turbines," Majlesi Journal of Mechatronic Systems, vol. 7, no. 4, pp. 15-23, 2018. [Online]. Available: http://journals.iaumajlesi.ac.ir/ms/index/index.php/ms/article/view/382.

[7] B. Abdesselem, B. Cherif and B. Othmane, "Cascade synergetic robust control power for wind speed variation based-on doubly-fed induction generator," Journal of Electrical and Electronics Engineering (JEEE), vol. 13, no. 2, $\quad$ pp. $39-44, \quad$ Oct $2020 . \quad$ [Online]. Available: https://www.proquest.com/openview/5aaeea489090ec88934e87d6f8276ccc/1.pdf?pq-rigsite=gscholar\&cbl=54417.

[8] H. Benbouhenni, Z. Boudjema and A. Belaidi, "Using four-level NSVM technique to improve DVC control of a DFIG based wind turbine systems," Periodica Polytechnica Electrical Engineering and Computer Science, vol. 63, no. 3, pp. 144-150, 2019, doi: 10.3311/PPee.13636.

[9] I. Yaichi, A. Semmah, P. Wira and Y. Djeriri, "Super-twisting sliding mode control of a doubly-fed induction generator based on the SVM strategy," Periodica Polytechnica Electrical Engineering and Computer Science, Vol. 63, no. 3, pp. 178-190, 2019, doi: 10.3311/PPee.13726.

[10] H. Benbouhenni, Z. Boudjema and A. Belaidi, "Direct vector control of a DFIG supplied by an intelligent SVM inverter for wind turbine system," Iranian Journal of Electrical and Electronic Engineering, vol. 15, no. 1, pp. 4555, 2019, doi: 10.22068/IJEEE.15.1.45

[11] H. Benbouhenni, "Comparative study between NSVM and FSVM strategy for a DFIG-based wind turbine system controlled by neuro-second order sliding mode," Majlesi Journal of Mechatronic Systems, vol. 7, no. 1, pp. 33-43, 2018. [Online]. Available: http://journals.iaumajlesi.ac.ir/ms/index/index.php/ms/article/view/360.

[12] H. Benbouhenni, Z. Boudjema and A. Belaidi, "Neuro-second order sliding mode control of a DFIG supplied by a two-level NSVM inverter for wind turbine system," Iranian Journal of Electrical and Electronic Engineering, vol. 14, no. 4, pp. 362-373, 2018, doi: 10.22068/IJEEE.14.4.362.

[13] H. Benbouhenni, Z. Boudjema and A. Belaidi, "A novel matlab/simulink model of DFIG drive using NSMC method with NSVM strategy," International Journal of Applied Power Engineering (IJAPE), vol. 8, no. 3, pp. 221233, 2019, doi: /10.11591/ijape.v8.i3.pp221-233.

[14] H. Benbouhenni, "Sliding mode with neural network regulateur for DFIG using two-level NPWM strategy," Iranian Journal of Electrical and Electronic Engineering, vol. 15, no. 3, pp. 411-419, 2019, doi: 10.22068/IJEEE.15.3.411.

[15] H. Benbouhenni, Z. Boudjema and A. Belaidi, "DFIG-based WT system using FPWM inverter," International Journal of Smart Grid, vol. 2, no. 3, pp. 142-154, 2018. [Online]. Available: https://www.ijsmartgrid.org/index.php/ijsmartgridnew/article/view/16.

[16] H. Benbouhenni, "Fuzzy second order sliding mode controller based on three-level fuzzy space vector modulation of a DFIG for wind energy conversion systems," Majlesi Journal of Mechatronic Systems, vol. 7, no. 3, pp. 17-26, 2018. [Online]. Available: http://journals.iaumajlesi.ac.ir/ms/index/index.php/ms/article/view/369.

[17] H. Benbouhenni, Z. Boudjema and A. Belaidi, "DFIG-based wind turbine system using four-level FSVM strategy," Majlesi Journal of Energy Management, vol. 6, no. 3, pp. 7-19, 2017. [Online]. Available: http://journals.iaumajlesi.ac.ir/em/index/index.php/em/article/view/334.

[18] H. Benbouhenni, "Comparison study between FPWM and NSVM inverter in neuro-sliding mode control of reactive and active power control of a DFIG-based wind energy," Majlesi Journal of Energy Management, vol. 6, no. 4, pp. 15-23, 2017. [Online]. Available: http://journals.iaumajlesi.ac.ir/em/index/index.php/em/article/view/338.

[19] H. Benbouhenni, "Intelligence indirect vector control of a DFIG based wind turbines," Majlesi Journal of Electrical Engineering, vol. 13, no. 3, pp. 27-35, 2019. [Online]. Available: http://mjee.iaumajlesi.ac.ir/index/index.php/ee/article/view/2972.

[20] H. Benbouhenni, Z. Boudjema and A. Belaidi, "A comparative study between four-level NSVM and three-level NSVM technique for a DFIG-based WECSs controlled by indirect vector control," Carpathian Journal of Electronic and Computer Engineering, vol. 11, no. 2, pp. 13-19, 2018, doi: 10.2478/cjece-2018-0012.

[21] H. Benbouhenni, "Direct vector control for doubly fed induction generator-based wind turbine system using fivelevel NSVM and two-level NSVM technique," International Journal of Smart Grid, vol. 3, no. 1, pp. 26-33, 2019. [Online]. Available: https://www.ijsmartgrid.org/index.php/ijsmartgridnew/article/view/39.

[22] H. Benbouhenni, "Stator active and reactive power ripples minimization for DVC control of DFIG by using fivelevel neural space vector modulation," Acta Electrotechnica et Informatica, vol. 19, no. 2, pp.16-23, 2019, doi: 10.15546/aeei-2019-0010.

[23] H. Benbouhenni, "Hybrid neural sliding mode control of a DFIG speed in wind turbines," Majlesi Journal of Energy Management, vol. 6, no. 4, pp. 31-41, 2017. [Online]. Avilable: http://journals.iaumajlesi.ac.ir/em/index/index.php/em/article/view/341.

[24] H. Benbouhenni, "A comparative study between DTC-NSTMC and DTC-FSTSMC control scheme for a DFIGbased wind turbine," Majlesi Journal of Energy Management, vol. 7, no. 4, pp. 43-53, 2018. [Online]. Available: http://journals.iaumajlesi.ac.ir/em/index/index.php/em/article/view/370.

[25] H. Benbouhenni, "Comparative study between PWM and SVPWM technique for a DFIG-based wind turbine system controlled by fuzzy sliding mode," Majlesi Journal of Energy Management, vol. 7, no. 4, pp. 13-20, 2018. [Online]. Available: http://journals.iaumajlesi.ac.ir/em/index/index.php/em/article/view/375. 
[26] H. Benbouhenni, "Rotor flux and torque ripples minimization for direct torque control of DFIG by NSTSM algorithm," Majlesi Journal of Energy Management, vol. 7, no. 3, pp. 1-9, 2018. [Online]. Available: journals.iaumajlesi.ac.ir/em/index/index.php/em/article/view/369.

[27] B. Habib, "New hybrid five-level space vector modulation strategy to minimize current distortion and power ripple for a DFIG controlled by NSOSMC control," Majlesi Journal of Energy Management, vol. 7, no. 2, pp. 33-44, 2018. [Online]. Available: journals.iaumajlesi.ac.ir/em/index/index.php/em/article/view/363.

[28] H. Benbouhenni, "Application of seven-level neural space vector PWM in direct vector control system of doubly fed induction generator for wind turbine," International Journal of Smart Grid, vol. 3, no. 3, pp. 163-171, 2019. [Online]. Available: https://www.ijsmartgrid.org/index.php/ijsmartgridnew/article/view/70.

[29] B. Habib, Z. Boudjema and A. Belaidi, "Intelligent SVM technique of a multi-level inverter for a DFIG-based wind turbine system," International Journal of Digital Signals and Smart Systems, vol. 3, no. 1, pp .4-19, 2019, doi: 10.1504/IJDSSS.2019.103372.

[30] B. Habib, Z. Boudjema, and A. Belaidi, "DFIG-based wind energy conversion system using five-level FSVM technique," International Journal of Renewable Energy Technology (IJRET), vol. 11, no. 2, pp. 147-164, 2020, doi: 10.1504/IJRET.2020.108300.

[31] H. Benbouhenni, "Stator current and rotor flux ripples reduction of DTC DFIG drive using FSTSMC algorithm," International Journal of Smart Grid, vol. 3, no. 4, pp. 226-234, 2019. [Online]. Avialable: https://www.ijsmartgrid.org/index.php/ijsmartgridnew/article/view/82.

[32] B. Habib, "Comparison study between SVPWM and FSVPWM strategy in fuzzy second order sliding mode control of a DFIG-based wind turbine," Carpathian Journal of Electronic and Computer Engineering, vol. 12, no. 2, pp. 1-10, 2019, doi: 10.2478/cjece-2019-0009.

[33] H. Benbouhenni, "A comparative study between NSMC and NSOSMC strategy for a DFIG integrated into wind energy system," Carpathian Journal of Electronic and Computer Engineering, vol. 12, no. 1, pp. 1-8, 2019, doi: 10.2478/cjece-2019-0001.

[34] B. Habib, "A comparison study between fuzzy PWM and SVM inverter in NSMC control of stator active and reactive power control of a DFIG based wind turbine systems," International Journal of Applied Power Engineering (IJAPE), vol. 8, no. 1, pp. 78-92, 2019, doi: 10.11591/ijape.v8.i1.pp78-92.

[35] H. Benbouhenni, Z. Boudjema and A. Belaidi, "Direct vector command based on three-level NSVM of a doubly fed induction generator for wind energy conversion," 2018 International Conference on Applied Smart Systems (ICASS), 2018, pp. 1-8, doi: 10.1109/ICASS.2018.8651957.

[36] H. Benbouhenni and Z. Boudjema, "Two-level DTC based on ANN controller of DFIG using 7-level hysteresis command to reduce flux ripple comparing with traditional command," 2018 International Conference on Applied Smart Systems (ICASS), 2018, pp. 1-8, doi: 10.1109/ICASS.2018.8652013.

[37] H. Benbouhenni, B. Zinelaabidine and B. Abdelkader, "Higher control scheme using neural second order sliding mode and ANFIS-SVM strategy for a DFIG-based wind turbine," International Journal of Advances in Telecommunications, Electrotechnics, Signals and Systems, vol. 8, no. 2, pp. 17-28, 2019. [Online]. Available: http://www.ijates.org/index.php/ijates/article/view/263.

[38] B. Habib, "Second order sliding mode with ANFIS controllers for DFIG using seven-level NSVPWM technique," Majlesi Journal of Energy Management, vol. 8, no. 1, pp. 29-39, 2019. [Online]. Available: http://journals.iaumajlesi.ac.ir/em/index/index.php/em/article/view/379.

[39] H. Benbouhenni, "ANFIS-sliding mode control of a DFIG supplied by a two-level SVPWM technique for wind energy conversion system," International Journal of Applied Power Engineering (IJAPE), vol. 9, no. 1, pp. 36-47, 2020, doi: 10.11591/ijape.v9.i1.pp36-47.

[40] B. Habib, B. Zinelaabidine and B. Abdelkader, "Comparison study between NPWM and NSVPWM strategy in FSMC control of stator reactive and active powers control of a DFIG-based wind turbine system,", International Journal of Applied Power Engineering, vol. 9, no. 2, pp. 159-172, 2020, doi: 10.11591/ijape.v9.i2.pp159-172.

[41] H. Benbouhenni, "Comparison study between seven-level SVPWM and two-level SVPWM strategy in direct vector control of a DFIG-based wind energy conversion systems,", International Journal of Applied Power Engineering (IJAPE), vol. 9, no. 1, pp. 12-21, 2020, doi: 10.11591/ijape.v9.i2.pp159-172.

[42] H. Benbouhenni, "Reducing current and torque ripples in DVC control of DFIG operation at constant switching frequency for wind generation application," Majlesi Journal of Energy Management, vol. 8, no. 4, pp. 47-55, 2019. [Online]. Available:. http://journals.iaumajlesi.ac.ir/em/index/index.php/em/article/view/402.

[43] B. Habib, "Torque ripple reduction of DTC DFIG Drive using neural PI regulators," Majlesi Journal of Energy Management, vol. $8, \quad$ no. 2, pp. 21-26, 2019. [Online]. Available: journals.iaumajlesi.ac.ir/em/index/index.php/em/article/view/384.

[44] B. Habib, "Utilization of an ANFIS-STSM algorithm to minimize total harmonic distortion," International Journal of Smart Grid, vol. 4, no. 2, pp. 56-67, 2020. [Online]. Available: https://www.ijsmartgrid.org/index.php/ijsmartgridnew/article/view/98.

[45] Y. Djeriri, "Commande directe du couple et des puissances d'une MADA associée à un système éolien par les techniques de l'intelligence artificielle,” Thése de Docorat, Universite Djillali Liabes de Sidi-Bel-Abbes, 2015.

[46] H. Benbouhenni, B. Zinelaabidine and B. Abdelkader, "Power Control of DFIG in WECS Using DPC and NDPCNPWM Methods," Mathematical Modelling of Engineering Problems, vol. 7, no. 2, pp. 223-236, 2020, doi: 10.18280/mmep.070208.

[47] H. Benbouhenni, "Twelve sectors DPC control based on neural hysteresis comparators of the DFIG integrated to wind power," TECNICA ITALIANA-Italian Journal of Engineering Science, vol. 64, no. 2, pp. 347-353, 2020, doi: 10.18280/ti-ijes.642-433. 
[48] H. Benbouhenni, Z. Boudjema and A. Belaidi, "Direct power control with NSTSM algorithm for DFIG using SVPWM technique," IJEEE Journal, vol. 17, no. 2, p. 1518, 2021, doi: 10.22068/IJEEE.17.1.1518.

[49] E. Heydari, M. Rafiee and M. Pichan, "Fuzzy-genetic algorithm-based direct power control strategy for DFIG," Iranian Journal of Electrical and Electronic Engineering, vol. 14, no. 4, pp. 353-361, 2018, doi: 10.22068/IJEEE.14.4.353.

[50] F. Amrane and A. Chaiba, "A novel direct power control for grid-connected doubly fed induction generator based on hybrid artificial intelligent control with space vector modulation," Revue Roumaine des Sciences Techniques Serie Électrotechnique et Énergétique, vol. 61, no. 3, pp. 263-268, 2016.

[51] L. Xu and P. Cartwright, "Direct active and reactive power control of DFIG for wind energy generation," in IEEE Transactions on Energy Conversion, vol. 21, no. 3, pp. 750-758, Sept. 2006, doi: 10.1109/TEC.2006.875472.

[52] B. Habib, "Application of five-level NPC inverter in DPC-ANN of doubly fed induction generator for wind power generation systems," International Journal of Smart Grid, vol. 3, no. 3, pp. 128-137, 2019. [Online]. Avilable: https://www.ijsmartgrid.com/index.php/ijsmartgridnew/article/view/66.

[53] H. Benbouhenni, B. Zinelaabidine and B. Abdelkader, "Sensorless twelve sectors implementation of neural DPC controlled DFIG for reactive and active powers ripples reduction," Majlesi Journal of Energy Management, vol. 7, no. 2, pp. 13-21, 2018. [Online]. Available: http://journals.iaumajlesi.ac.ir/em/index/index.php/em/article/view/355.

[54] E. G. Shehata, "Sliding mode direct power control of RSC for DFIGs driven by variable speed wind turbines," Alexandria Engineering Journal, vol. 54, no. 4, pp. 1067-1075, 2015, doi: 10.1016/j.aej.2015.06.006.

[55] S. G. Shehata, M. Gerges and M. Salama, "Direct power control of DFIGs based wind energy generation systems under distorted grid voltage conditions," International Journal of Electrical Power \& Energy Systems, vol. 53, pp. 956-966, 2013, doi: 10.1016/j.ijepes.2013.06.006.

[56] A. Yahdou, B. Hemici and Z. Boudjema, "Second order sliding mode control of a dual-rotor wind turbine system by employing a matrix converter," Journal of Electrical Engineering, vol. 16, no. 3, 2016. [Online]. Available: http://new.jee.ro/index.php/jee/article/view/WO1439151618W55c7b6024978d.

[57] A. Yahdou, B. Hemici and Z. Boudjema, "Sliding mode control of dual rotor wind turbine system," The Mediterranean Journal of Measurement and Control, vol. 11, no. 2, pp. 412-419, 2015.

[58] A. Yahdou, A. B. Djilali, Z. Boudjema and F. Mehedi, "Improved vector control of a counter-rotating wind turbine system using adaptive backstepping sliding mode," Journal Européen des Systèmes Automatisés, vol. 53, no. 5, pp. 645-651, 2020, doi: 10.18280/jesa.530507.

[59] N. A. Yusoff, A. M. Razali, K. A. Karim, T. Sutikno and A. Jidin, "A Concept of Virtual-Flux Direct Power Control of Three-Phase AC-DC Converter," International Journal of Power Electronics and Drive System, vol. 8, no.4, pp.1776-1784, 2017, doi: 10.11591/ijpeds.v8i4.pp1776-1784.

[60] F. Amrane, A. Chaiba, B. E. Babes and S. Mekhilef, "Design and implementation of high performance field oriented control for grid-connected doubly fed induction generator via hysteresis rotor current controller," Revue roumaine des sciences techniques Série Électrotechnique et Énergétique, vol. 61, no.4, pp. 319-324, 2016. [Online]. Available: http://revue.elth.pub.ro/viewpdf.php?id=609.

[61] Z. Boudjema, A. Meroufel, Y. Djerriri and E. Bounadja, "Fuzzy sliding mode control of a doubly fed induction generator for energy conversion," Carpathian Journal of Electronic and Computer Engineering, vol. 6, no.2, pp.714,2013

[62] Z. Boudjema, R. Taleb, Y. Djerriri and A. Yahdou, "A novel direct torque control using second order continuous sliding mode of a doubly fed induction generator for a wind energy conversion system," Turkish Journal of Electrical Engineering \& Computer Sciences, vol. 25, no.6, pp. 965-975, 2017, doi: 10.3906/elk-1510-89.

[63] A. Fayssal, F. Bruno and C. Azeddine, "Experimental investigation of efficient and simple wind-turbine based on DFIG-direct power control using LCL-filter for stand-alone mode," ISA Transactions, 2021, doi: 10.1016/j.isatra.2021.07.008.

[64] H. Benbouhenni and N. Bizon, "A Synergetic Sliding Mode Controller Applied to Direct Field-Oriented Control of Induction Generator-Based Variable Speed Dual-Rotor Wind Turbines," Energies, vol. 14, no. 15, p. 4437, 2021, doi: $10.3390 /$ en14154437.

\section{BIOGRAPHIES OF AUTHORS}

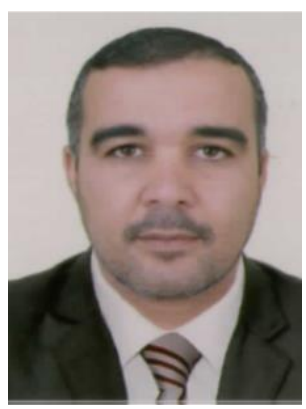

H. Benbouhenni was born in chlef, Algeria. He is Teacher in university of Nisantasi, Istanbul, Turkey. $\mathrm{He}$ received a $\mathrm{PhD}$ in Electrical Engineering from the Departement of Electrical Engineering, ENPO-MA, Oran, Algeria. He received M.A. degree of automatic and informatique industrial in 2017. His research activities include the application of robust control in the wind turbine power systems. 